\title{
THE VESTAL HABIT
}

\author{
Andrew B. Gallia*
}

In her epochal study of the Vestal virgins, Mary Beard called attention to the ambiguous position of these priestesses in relation to the normative categories of gender in Roman society. ${ }^{1}$ Drawing on the insights of structural anthropology, she argued that this ambiguity was central to the Vestals' sacredness. Essentially, her interpretation rests on the proposition that, by combining features relating to the status of unmarried daughters (virgines) with those of married women (matronae), the priestesses became in themselves vessels for the symbolic mediation between culturally opposed categories that Claude Lévi-Strauss, Mary Douglas, and others have identified as a central function of myth and ritual. ${ }^{2}$ Although the underlying observation about the peculiarity of the Vestals' "sexual status" must ultimately be allowed to stand, more recent work on the inherent instability of categories of sex and gender suggests that we ought to revisit the problem of the priestesses' ambiguity, paying closer attention to the socially contingent nature of its production. ${ }^{3}$

In this article, I will confine my discussion to an aspect of gender construction that Beard regarded as essential to establishing the matronal piece of the Vestals' supposed interstitiality:

\footnotetext{
${ }^{*}$ Published in Classical Philology 109.3 (2014).

${ }^{1}$ Beard 1980.

${ }^{2}$ Beard 1980, 23-4; cf. Lévi-Strauss 1955, 437-42; Douglas 1969, 163-70; Leach 1976, 34-6.

${ }^{3}$ Butler 1990; Fausto Sterling 2000. For social-historical critiques of Beard's original thesis, see Gardner 1986, 22-6; Cancik-Lindemaier 1990; Scardigli 2003; Gallia 2015. Note also the subsequent self-critique of Beard 1995, although this account is avowedly "not concerned with "how the facts fit"' (169).
} 
their ritual costume. ${ }^{4}$ The importance of dress as a system of signs through which categories of sex and gender (not to mention age, status, ethnicity, and any number of other aspects of identity) are negotiated makes this a subject of obvious importance for the study of Roman culture as a whole. ${ }^{5}$ Authors such as Cicero and Ovid often refer to clothes as a way to invoke other concepts, but just as the ubiquity of clothing gives it its power as a system of cultural meaning, the implicit nature of this system also makes it susceptible to misinterpretation by outsiders. For guidance on the significance of particular articles of clothing, modern scholars are left in the hands of the antiquarians and lexicographers, where treatment is ad hoc and fragmentary, making systematic analysis difficult. By reexamining the distinctive costume of the Vestal virgins, I hope to shed new light on the way that Romans used clothing to express concepts of gender and sexuality more generally. Rather than see the overlap between the dress of this narrow subgroup of Roman females and that of other women as confounding, I argue that each element of the Vestals' wardrobe helped to reinforce the importance of basic principles of sexual decorum, according to which gender roles were typically constructed in Roman society.

The interpretation of the Vestals' ritual attire has long been a central concern in discussions of their place in Roman state cult. In particular, scholars who identified the origins of this priesthood in the religious duties of the wives of Rome's early kings have pointed to those articles of clothing that are also characteristic of matrons (their vittae, or headbands, and stola, or floor-length gown) and brides (the "six-lock" hairstyle, or seni crines, and belt tied in a square

\footnotetext{
${ }^{4}$ Beard 1980, 16.

${ }^{5}$ See, for example, Roach and Eicher 1965; Barthes 1983; also Leach 1976, 55. For the recent upsurge of interest in Roman dress specifically, see Sebesta and Bonfante 1994; Edmondson and Keith 2008; Olson 2008b.
} 
knot, or nodus Herculaneus). ${ }^{6}$ Shifting the grounds of the debate away from speculative aetiological explanation, Beard read these sartorial markers as evidence for a symbolic affinity with the category of matrons, which produced the above-mentioned ambiguity when combined with the obvious fact that the Vestals' physical virginity precluded them from the status of mothers and wives. ${ }^{7}$ More recently, scholars have begun to downplay the significance of these symbolic connections, although the discussion has centered predominantly on the priestesses' legal status and other, non-sartorial, aspects of their religious identity. ${ }^{8}$ Despite new interpretations that have been proposed for individual aspects of the Vestal costume (especially their hairstyle), a systematic reconsideration of Beard's ideas about category confusion has yet to appear. ${ }^{9}$ In the most thorough recent account of the Vestals' clothing, Nina Mekacher merely emphasizes the hybrid nature of their ensemble, which she claims marked the priestesses out as sui generis. ${ }^{10}$ In the following discussion, I begin by reviewing the individual points of overlap between the Vestals' wardrobe and that of other categories of women before returning to the underlying logic of the costume as a whole in the conclusion.

\footnotetext{
${ }^{6}$ Jordan 1886, 43-5; Dragendorff 1896; Guizzi 1968, 109-11.

${ }^{7}$ Beard 1980, 16.

${ }^{8}$ See esp. Parker 2004; Martini 2004; also Kroppenberg 2010.

${ }^{9}$ Staples (1998, 145-7) and Martini (1997, 477-90) essentially accept Beard's conclusions about the Vestals' attire, extending the implications of the priestesses' supposed liminality in slightly different directions. Wildfang (2006, 11-16) comes closest to the conclusions offered here, but offers no explicit critique of Beard's formulations.

${ }^{10}$ Mekacher 2006, 48-9: "In ihrer spezifischen Ausprägung und Zusammensetzung sind sie aber allein für die Priesterinnen charakteristisch und stellen einen ausschliesslich von ihnen getragenen Ornat dar."
} 
We can dispense with the first item in the list of supposedly matronal clothing relatively quickly. Vittae, the cloth ribbons with which the Vestals bound their hair, were perhaps the most recognizable feature of their attire. These bands are clearly depicted in almost all of the visual representations of the priestesses that have come down to us. In some cases, Vestals are represented as crowned by bands of infulae, the woolen fillets that Romans placed on their heads when offering sacrifices, while the looped ends of the vittae hang down at the back of the neck (fig. 1). ${ }^{11}$ References to Vestal vittae also appear frequently in the literary sources, and they are probably what Dionysius of Halicarnassus is referring to when he recounts the story of how Aemilia, a priestess in the third century B.C.E., miraculously revived Vesta's fire by removing a linen strap ( $\tau \varepsilon \lambda \alpha \mu \omega \dot{v})$ from her clothing and placing it on the hearth (Ant. Rom. 2.68.5). ${ }^{12}$ The cultural association of the Vestal virgins with their hairbands was certainly very strong.

\footnotetext{
${ }^{11}$ Mekacher 2006, 45-46; cf. Dragendorff 1896, 286-7. On the relationship between vittae and infulae, see Serv. Aen. 10.538; Isid. Etym. 19.30.4; Fantham 2008; Stephens 2013. The only ancient authorities to explicitly mention Vestal infulae are Christians (Prudent. C. Symm. 2.1085; Ambrose Ep. 18.11).

${ }^{12}$ Cf. Val. Max. 1.1.7; Prop. 4.11.53-4. This evidence is construed differently by Martini 1997, 483. For vittae as characteristic of Vestal virgins, see Ov. Fast. 3.29-30, 6.457; Juv. 4.9-10; Symmachus Relat. 3.11.
} 


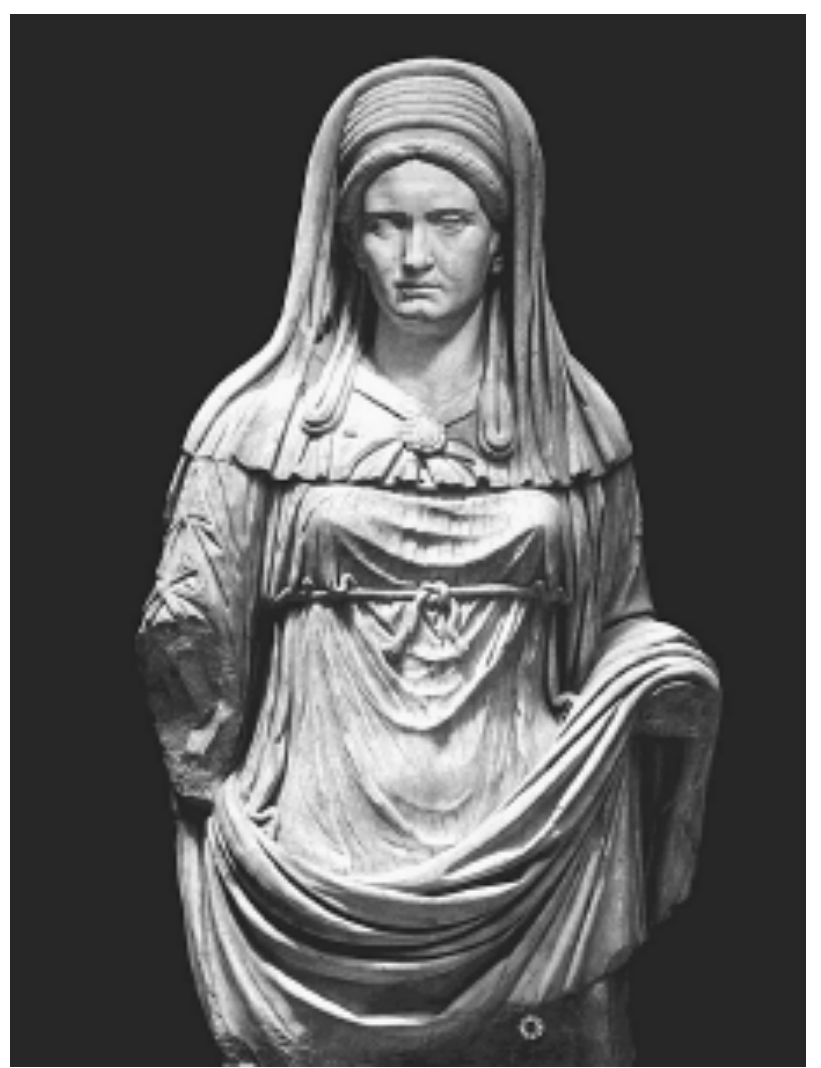

Figure 1. Portrait of a Vestal virgin (Antonine). Rome, Museo Nazionale, Palazzo Altemps Inv. 639.

It is also true that vittae were closely associated with the status of the Roman matron. ${ }^{13}$ Valerius Maximus (5.2.1a) goes so far as to suggest that the privilege of wearing these headbands (along with purple garments and gold beadwork) was granted to the ordo matronarum by the senate in recognition of the role played by Coriolanus' wife and mother in averting the exiled commander's wrath from Rome. But Varro is quoted as saying that young girls also wore "hair carefully combed, with the locks bound up" (capillo pexo, utique innexis crinibus, de Vita Populi Romani 62S, ap. Non. 353L), the only difference being that their heads were otherwise

${ }^{13}$ Plaut. Mil. 791-2; Verg. Aen. 7.403; Tib. 1.6.67-8; cf. Ov. Ars am. 1.31-2. Beard 1980, 16; Sebesta 1994, 49; Olson 2008b, 36-9. 
uncovered when they went out in public. ${ }^{14}$ In one of Propertius' elegies, Cornelia refers to her marriage as a time when "a different headband" (altera vitta, 4.11.34) was placed on her hair. Whether this change involved the color, width, or fabric of the vitta is not known. ${ }^{15}$ What is clear is that vittae in themselves did not necessarily denote any particular stage of the female life course. Because these bands were available to unmarried girls, matrons, and the Vestal virgins alike, they had to be viewed in the context of other sartorial markers for the uniquely differentiated meanings associated with such categories to emerge. On their own, vittae could only suggest some feature held in common by all three.

Judging from the manner in which they were worn, the vittae of the Vestal virgins might be seen as creating a unique connection with the costume of the Roman bride. Bridal vittae are mentioned in another passage of Propertius (4.3.15-16), but to my knowledge their use has not been adequately accounted for in this context. ${ }^{16}$ In visual representations of the marriage ceremony, the ornamentation of the bride's hair is typically obscured by the veil, making direct comparison impossible. ${ }^{17}$ Unveiled portraits of Vestals do exist, however, and from these it is clear that the vittae were integral to the structure of their distinctive, elaborate hairstyle. This was the coiffure of the seni crines, which Festus indicates was worn by Roman brides and Vestal virgins alike (454L, quoted below). Although the nature of the seni crines has become a source

${ }^{14}$ Sebesta 1994, 47; Olson 2008a, 143-4. Matrons were expected to wear a mantle, or palla, over their heads in public: Val. Max. 6.3.10; Plut. Mor. 267C; Levine 1995, 103; Fantham 2008, 160; cf. El Guindi 1999, 77-96; Llewellyn-Jones 2003, 189-208. Here and throughout, all translations are my own.

${ }^{15}$ Of all Roman women, only the portraits of the Vestals consistently represent their headbands (see below). Even this small sample reveals minor variations in style of wear, however.

16 See Sebesta 1994, 48; La Follette 1994, 59-60; Hersch 2010, 73-89; cf. Jordan 1886, 48 n. 5. ${ }^{17}$ La Follette 1994, 57. 
of much scholarly confusion and debate, it seems to me that the best explanation of the term may be to read it as referring to the division of the hair into six strands, three on either side of the head, which were then braided into pigtails. ${ }^{18}$ As can be seen in portraits such as the Uffizi bust (fig. 2), these braids were wrapped around the head horizontally and secured in place by the bands of the vittae, which surround the whole edifice like a turban. ${ }^{19}$
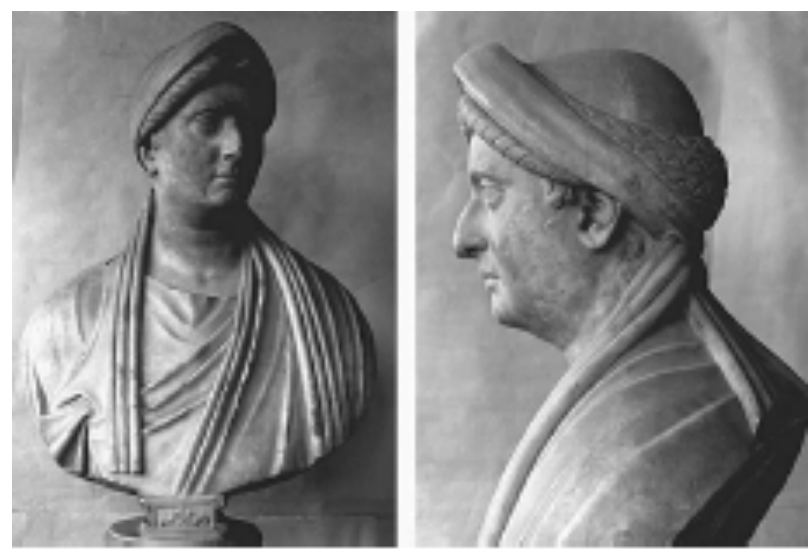

Figure 2. Portrait head of a Vestal virgin (Hadrianic). Florence, Galleria degli Uffizi Inv. 1914.150.

In addition to their carefully wrapped hairstyle, the dress of the Vestals corresponded to that of brides in the way that their gowns were girded as well. The visual record depicts the

\footnotetext{
${ }^{18}$ Dragendorff 1896, 286; cf. Siebert 1995, 83-7; Mekacher 2006, 45-6; Stephens 2013. For other interpretations, see also Jordan 1886, 47-9; Sensi 1980-81, 67-70; Giannecchini 1980-81; Torelli 1984, 33-41; La Follette 1994, 56-60; La Follette and Wallace 1993; Olson 2008b, 22-4. ${ }^{19}$ The Vestal on panel B of the Cancelleria relief (fig. 3) is thought by some to have short hair, leading La Follette $(1994,57-60)$ to argue that the Vestals' hair was actually cut short, and that infulae were then wrapped around the head as a woolly wig-like imitation of the seni crines (cf. Jordan 1886, 49; also Sensi 1980-81, 68-9; Martini 1997, 477-9). The Elder Pliny's reference to the lotos capillata (HN 16.235, cf. Paul. Fest. 50L) notwithstanding, I interpret the bulkiness of her head wrappings as suggesting the presence of braids under thin vittae rather than as a depiction of thick infulae over close-cropped hair. Cf. Stephens 2013. Whether some Vestals used wigs to simulate a hairstyle that otherwise might have been inconvenient to maintain is a different question, of course (cf. Dragendorff 1896, 288; Siebert 1995, 86).
} 
priestesses with belts tied in the square or "Herculanean" knot (figs. 1, 4) ${ }^{20}$ Describing the woolen belt (cingillum) worn by brides, Festus explains that it was secured with this knot, although exclusive application of the knot in this context is not implied (hunc Herculaneo nodo vinctum vir solvit ominis gratia, 55L). ${ }^{21}$ As Beard recognized, such connections between the appearance of the Vestals and that of brides lend particular weight to an interpretation of the priestesses as icons of ambivalence: "like the girl on the day of her wedding, they are seen as on the brink between virginal and marital status, but perpetually on the brink, perpetually fixed at the moment of transition from one category to another.",22

${ }^{20}$ Dragendorff 1896, 289. Noting the absence of literary references, Mekacher $(2006,48)$ downplays the importance of the nodus Herculaneus, explaining it as a convention of late Hellenistic art. As van Deman 1908 established, the posture and draping of the full-length statues discovered in the vicinity of the Atrium Vestae in Rome reflect the standardized typologies of workshop copies, which undermines their value as evidence for the Vestals' actual appearance. Such concerns obviously have no bearing on the Flavian-era Palermo relief (fig. 4), which should be regarded as a more accurate representation of the Vestals' costume (cf. Ryberg 1955, 51-3; Mekacher 2006, 157-8).

${ }^{21}$ Cf. Plin. HN 28.64, discussing other magical benefits of the nodus Herculis. Festus (loc. cit.) suggests that the knot was propitious for the fertility of the husband when he unbound it, because Hercules had fathered seventy children. See also Hersch 2010, 110-12.

${ }^{22}$ Beard 1980, 21; cf. Leach 1976, 55-6. See also Staples 1998, 146; Wildfang 2006, 12-13. Contra, Hersch 2010, 75-6. 


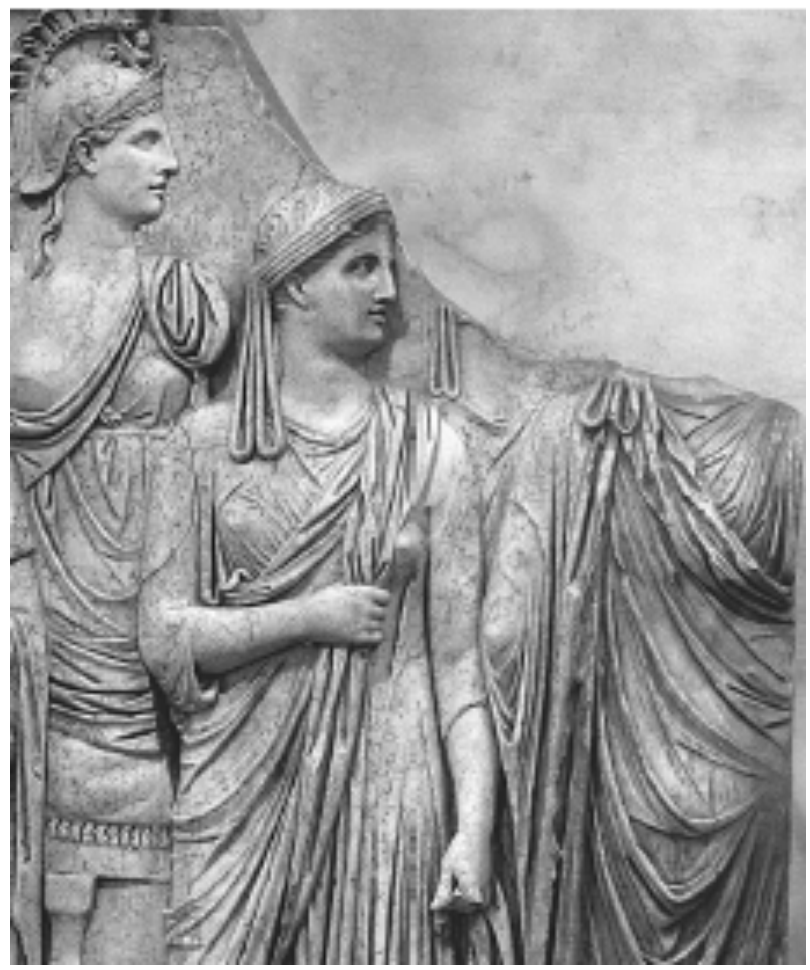

Figure 3. Cancelleria Relief, Panel B (Flavian), detail. Vatican, Museo Gregoriano Profano Inv. 13392.

The overlap in costume is only partial, however, and we should be cautious about embracing an interpretation that casts the Vestals as the Miss Havishams of ancient Rome. There were key elements in the dress of brides that the Vestals did not share. Most notably, the Vestals did not veil themselves with the bright yellow flammeum, as brides (and, significantly, the flaminica Dialis, or wife of the priest of Jupiter) did. ${ }^{23}$ Instead, when Vestal virgins appeared on ritual occasions, their heads were covered with the suffibulum, a cowl-like, shoulder-length veil, which was white with a purple border and fastened in front with a brooch (album, praetextum,

${ }^{23}$ La Follette 1994, 55-6; Sebesta 1994, 48; Torelli 1984, 42-3; Staples 1998, 78-9; Hersch 2010, 94-106. In Paul's epitome of Festus, the flammeum is construed as a good omen for brides because the flaminica, who also wore it, was not allowed to get divorced (cui non licebat facere divortium, 79L; cf. 82L). 
quadrangulum, oblongum ... idque fibula conprehenditur, Festus 474L; figs. 1,4$).{ }^{24}$ It would be difficult to mistake one head covering for the other, especially when the long, colorful flammeum already had its own special association with the priestly identity of the flaminica. ${ }^{25}$

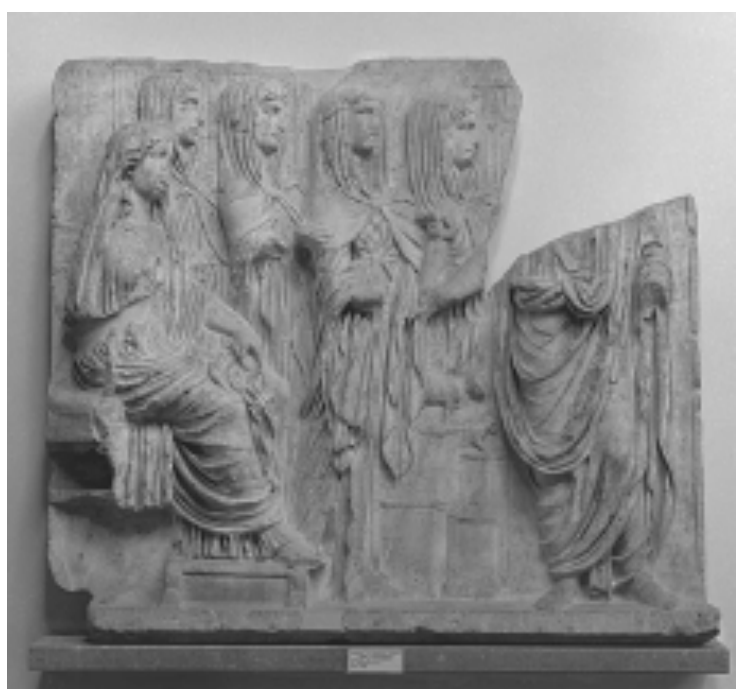

Figure 4. Relief of Vesta with Vestal virgins (Flavian). Palermo, Museo Archeologico Regionale Inv. 1539.

Furthermore, the Vestals wore the long, flowing stola associated with matrons instead of the wide-cut tunica recta (or regilla) of the bride. ${ }^{26}$ This departure from the standard attire of the bride is of even greater importance for our understanding of the overall significance of the Vestals' wardrobe. Once again, Festus informs us that the bridal garment in question did not have an exclusive association with a single category of individuals: it was also worn by boys when they received the toga virilis (ut etiam in togis virilibus dandis observari solet, 364L; cf. Plin. $H N$ 8.124) ${ }^{27}$ This similarity of dress was obviously not meant to suggest that boys entering upon manhood were just like brides (or vice versa). It seems more likely that the tunica recta

${ }^{24}$ Cf. Varr. Ling. 6.21, Ryberg 1955, 41, 52; Mekacher 2006, 45.

${ }^{25}$ Pace Dragendorff 1896, 291-4.

${ }^{26}$ Vestal stola: Plin. Ep. 4.11.9; Mekacher 2006, 47; Wildfang 2006, 13-14; pace Martini 1997, 483-6. Tunica recta: Plin. HN 8.194; Festus 364L; La Follette 1994, 54-5; Hersch 2010, 108-9. ${ }^{27}$ La Follette 1994, 55. 
marked the transition into adulthood that was common to both, even as the normative expectations of Roman gender roles required that this rite of passage operated quite differently for males and females. ${ }^{28}$ If this interpretation of the tunica recta as a garment of initiation is correct, its absence from the list of features that Vestals shared with brides suggests that the meaning of those other items (hairstyle, belt fastening) might not have anything to do with being "perpetually" - or even temporarily_ “on the brink." I will come back to the nature of this connection shortly.

From the material discussed so far, we can begin to see that individual articles of clothing, such as the flammeum and tunica recta of brides, as well as the vittae and stola of matrons were regularly worn in different contexts by different categories of people in Roman society. Perhaps the most intriguing example of this principle of boundary-crossing is the toga itself, which not only marked the status of the adult (male) Roman citizen, with all its pride and consequence (cf. Verg. Aen. 1.282), but was also, perplexingly, the garment assigned to female prostitutes and adulteresses. ${ }^{29}$ It will be worthwhile to digress at this point to consider the dual nature of the toga, as the unraveling of this problem will provide a productive context in which to consider the relationship between the Vestals' unique ensemble and their sexuality.

Cicero aptly exploits the inherent ambivalence of the toga in his account of Antony's dissolute youth (Phil. 2.44):

${ }^{28}$ Torelli 1984, 26; Hersch 2010, 66.

${ }^{29}$ [Tib.] 3.16.3-5; Mart. 2.39; Afranius ap. Non. 867L; [Acro] ad Hor. Sat. 1.2.63. McGinn 1998, 156-71; Olson 2002, 393-7. 
sumpsisti virilem, quam statim muliebrem togam reddidisti. primo vulgare scortum; certa flagiti merces nec ea parva; sed cito Curio intervenit, qui te a meretricio quaestu abduxit et, tamquam stolam dedisset, in matrimonio stabili et certo conlocavit.

You took up the toga of a man, which you promptly rendered womanly. At first, you were a common whore; the price of your shame was fixed, and it was not small. But soon Curio came along and took you out of the prostitute's trade, as if he had given you a stola and settled you in a stable and steady marriage.

In this passage, the difference between the toga virilis and the toga muliebris lies not in the garment itself, but in the nature of the person who wears it. Its significance derives not simply from Antony's employment as a prostitute, but, more specifically, from his implied effeminacy as the passive partner in those sexual exchanges. Following the misogynist logic of this invective, this feminine quality is what endures when Antony exchanges his whore's toga for the metaphoric stola he receives from his new patron—or "husband"-Curio. ${ }^{30}$

Why was the toga, when worn by a woman, the mark of a whore in Roman culture? Varro offers the expected aetiological red herring when he claims that the toga had once been "the common dress, both in day and at night, for women and men alike" (ante enim olim toga fuit commune vestimentum et diurnum et nocturnum et muliebre et virile, de Vita Populi Romani 56S, ap. Non. 867-8L; cf. Serv. Aen. 1.282). The reasoning that seems to follow from this claim is that the stola was subsequently adopted as the sign of respectable Roman matrons, at which

\footnotetext{
${ }^{30}$ Heskel 1994, 140-41; cf. Petron. Sat. 81.5. See also Edwards 1993, 63-97. For a broader view of Cicero's use of "sartorial invective" in the speeches, see also Dyck 2001.
} 
point the primordial toga was left over as the garment of unmarried adult women, who, faute de mieux, were categorized as prostitutes. ${ }^{31}$ Such an explanation has the veneer of plausibility, but it does not account for the dress of concubines, or explain why an important sub-group of unmarried women - the Vestal virgins - were allowed to wear the stola. The Romans certainly would not want to mistake a Vestal for a prostitute, but to follow Varro's line of explanation requires that we muddle the question further by positing an additional stage of cultural development, involving the later assimilation (whether pseudo-aetiological or symbolic) of Vestals to the status of matrons.

A better approach is to look at the implications of these articles of clothing from a structural point of view. Let us place the stola, the common dress of Vestals and matrons, on one side and the toga, as worn by adult men and whores, on the other. Viewed in this way, the social categories associated with these garments produce a clear axis of sexual restraint or availability. The sexuality of the Vestal virgins was obviously the most restricted. To violate the chastity of a Vestal was to commit incestum, a crime punished with death. ${ }^{32}$ Similarly, adulterous sexual activity involving a matron was a form of stuprum, which had been dealt with harshly even before the severe penalties imposed under the Augustan lex Julia de adulteriis. ${ }^{33}$ By covering

${ }^{31}$ Dyck 2001, 127 n. 28.

${ }^{32}$ Livy 22.57.2-3; Dion. Hal. Ant. Rom. 8.89.4-5; Plut. Num. 10.4-7, cf. Mor. 286F. Lovisi 1998, 721-35; Staples 1998, 132.

${ }^{33}$ Dig. 50.16.101.praef. (Modestinus), cf. 48.5.6.1 (Papinian). Treggiari 1991, 268-87; Fantham 1991; McGinn 1998, 140-45; cf. Williams 1999, 119-24. 
their bodies with the long, flowing stola when they appeared in public, both matrons and Vestals signaled the prohibitions that governed their sexuality. ${ }^{34}$

Under to the terms of an old law recorded by Valerius Maximus, the message conveyed by the stola was, quite literally, "hands off" (ut inviolata manus alienae tactu stola relinqueretur, 2.1.5a). According to this principle, the married woman who went out without the protection of this garment put her chastity at risk. Such behavior apparently exercised Tiberian-era moralists like Caecina Severus, and Tertullian records the terms of a senatorial decree carried by Severus' contemporary, the augur $\mathrm{Cn}$. Cornelius Lentulus, to the effect that any matron who failed in her duty to wear the stola should be punished as if she had committed stuprum (pro stupro erat poena, de Pallio 4.9). ${ }^{35}$ Conversely, an adulteress had no chastity to protect, and thus was forbidden to wear the stola. Starting in the age of Augustus, when adultery became a matter for public prosecution under the lex Julia, such women became, like prostitutes, associated with the toga. $^{36}$

Although men might complain about the inconvenience of the toga and the difficulty of wearing it properly (cf. Tert. de Pallio 5.1-2), this was in important ways a less restrictive garment than the stola, insofar as it left one shoulder bare and did not fully cover the legs. In

\footnotetext{
${ }^{34}$ Sebesta 1997, 535-7; Wildfang 2006, 13-14; Olson 2008b, 31; Gallia 2012, 119; cf.
} Llewellyn-Jones 2003, 156-80. It must be conceded that the castitas of matrons (who were available to their husbands as sexual objects) was of a different order from that of the Vestal virgins, but this need not undermine the interpretation offered here (see below). Even the most old-fashioned of Roman wives would not have worn the stola when she slept with her husband. ${ }^{35}$ PIR ${ }^{2}$ C 106, 1379; cf. Tac. Ann. 3.33.4, also 2.85.1-3. See also Olson 2002, 399-400 on Tertullian's reasons for citing this decree, and Edmondson 2008, 24 on legislative attempts to regulate dress.

${ }^{36}$ McGinn 1998, 163-71; cf. Olson 2002, 393-5. 
contradistinction to the long, flowing stola, therefore, the toga marked an absence of external constraints on an adult wearer's sexuality. Just as the tunica recta was worn by both boys and girls at their respective transitions into adulthood, this explanation of the toga's significance can apply equally to men and women, even as phallocentric assumptions about sex and gender roles created radically different contexts for understanding its implications. For the Romans, it was only "natural" that adult men should be in charge of their own sexuality. The assumption of the toga virilis signaled one's transformation from the status of a puer, who was potentially vulnerable to penetration, into a mature and fully-formed sexual subject, who was able to penetrate others as he wished. ${ }^{37}$ Roman women, on the other hand, were by definition denied this kind of subjectivity. According to the normative gender categories available to them, the only meaningful control that could be exercised over their sexuality consisted in placing it off limits. The toga thus held shameful associations for women, not because in wearing it they acted as men per se, but because it marked their bodies as lacking the chastity that was necessary for them to secure a respectable position in society.

This interpretation of the toga-stola dichotomy does not necessarily preclude interpretations of the woman's toga as a kind of "symbolic transvestism," but it does suggest important limitations on how far that concept can be pressed. ${ }^{38}$ Discussing the appropriate case

${ }^{37}$ Parker 1997, 58-9; Williams 1999, 17-19. The obligation for men to refrain from intercourse defined as stuprum or incestum obviously depends upon this more fundamental notion of power, and the self-control that derives from it.

${ }^{38}$ Cf. McGinn 1998, 164, 209-11; also Heskel 1994, 141: "perhaps such women (sc. prostitutes) were believed to behave like men, that is, in their promiscuous actions." The expectation that promiscuous women would also transgress the limits imposed upon their gender in other, nonsexual ways might encourage some play on the meaning of the prostitute's toga (e.g., Juv. 2.6570 , where the satirist's real target is the multicia of a male advocate), but the principle 
endings for masculine names of the first declension, Varro analogizes to the difference between men's and women's tunics (Ling. 10.27):

in quis figuris non ea similia dicemus quae similis res significant, sed quae ea forma sint, ut eius modi res similis ex instituto significare plerumque soleant, ut tunicam virilem et muliebrem dicimus non eam quam habet vir aut mulier, sed quam habere ex instituto debet: potest enim muliebrem vir, virilem mulier habere, ut in scaena ab actoribus haberi videmus.

Among these forms, we shall not call those similar which represent similar things, but those which are of the form that by custom are generally liable to represent things of a similar type. Thus the tunic we refer to as manly or womanly is not that which a man or a woman wears, but is that which he or she is expected to wear by custom: for a man can wear the womanly one, and a woman the manly, as we see them worn by actors on the stage.

The wristwatch provides a convenient modern parallel: It is unremarkable for either a man or a woman to wear one, but we are likely to notice when a watchband designed for a woman appears around a man's wrist (or vice versa). ${ }^{39}$ Gradations of fabric, cut, and color might differentiate the clothing of particular groups (and thus mark out the cross-dresser), but there is nothing

nevertheless remained that the toga of a man haranguing a crowd from the Rostra was regarded differently from that of a disgraced woman, much less one soliciting customers from under the porticoes of the Circus Maximus: cf. Tac. Dial. 26.1, Quint. Inst. 11.3.131, 137-49.

39 This scenario is also invoked, to different purpose, by Parker 1997, 60. 
inherently transgressive about wearing a garment that is appropriate to one's station.$^{40}$ Insofar as it was a normal feature of the Roman system of dress for the same basic categories of garment to be worn by different types of people in different contexts, it follows that the specific meaning of these articles of clothing derived in large part from the context and manner in which they were worn. ${ }^{41}$ This principle has important implications for the dress of the Vestal virgins, but there is still one more piece of evidence relating to the female toga to consider before we can return to our main topic.

The maiden Cloelia, who organized an escape of hostages from the camp of Lars Porsenna at the dawn of the Roman Republic, had a famous equestrian statue along the Sacra Via, which Pliny the Elder suggests depicted her "wrapped in a toga" (toga eam cingi, $H N$ 34.28). ${ }^{42}$ Seneca, reflecting on a long line of exemplary discourse about Cloelia's deeds, notes that the honors bestowed on this heroine all but assimilated her to the status of a man, whose characteristic virtus she more than equaled (ob insignem audaciam tantum non in viros transcripsimus, ad Marciam 16.2). ${ }^{43}$ Could the togate representation of this female be meant as a more positive form of "symbolic transvestism," that is, as a way of marking her masculine bravery by presenting her in the dress of a man? Certainly, there cannot have been any intent to

${ }^{40}$ Cf. Dig. 34.2.23.2 (Ulpian), defining the various categories of clothing (virilia, puerilia, muliebria, etc.): communia sunt, quibus promiscui utitur mulier cum viro, veluti si eiusmodi penula palliumve est et reliqua huiusmodi, quibus sine reprehensione vel vir vel uxor utatur. ${ }^{41}$ Thus Davies $(2005,121)$ on the toga: "What makes the garment virilis is not so much the toga itself as how it is worn, and the behaviour of the wearer." Cf. Leach 1976, 55; Barthes 1983, 5986; also El Guindi 1999, 117-28.

${ }^{42}$ Cf. Livy 2.13.6-11; Dion. Hal. Ant. Rom. 5.33-5; Val. Max. 3.2.2. On the statue, see LTUR II, 226 s.v. "Equus: Cloelia" (Papi), Roller 2004, 44-9.

${ }^{43}$ Cf. Livy 2.13.11; Manilius 1.780; Roller 2004, 38-50. 
portray her as a prostitute. Cloelia was, rather emphatically, a virgo, whose heroism saved not only herself, but also other vulnerable children (impubes) from the threat of defloration by their Etruscan captors (Livy 2.13.10). As it turns out, the solution to this conundrum lies in the fact of Cloelia's virginity. We must recognize that her toga was not that of an adult (man or prostitute), but rather it should be understood as the purple-bordered toga praetexta worn by freeborn children of both genders. ${ }^{44}$ The clothing depicted on the statue is thus in keeping with Cloelia's youthful station. It has nothing to do with the paradox of her virginal virtus, which seems to have been conveyed in the honor of the equestrian statue itself.

Beyond its use by minors, the toga praetexta was also worn by curule magistrates and certain priests, providing yet another instance of overlapping categories. ${ }^{45}$ In this case, Lynn Sebesta has provided the needed explanation. Drawing on Festus' definition of "praetextate speech" (praetextus sermo, 282-4L) and other passages which stress the injunction against exposing children (praetextati) to obscenity, she suggests that the purple border of such garments signified the chastity associated with its wearer. ${ }^{46}$ This symbolism applied not only to freeborn children, whose vulnerability as potential objects of stuprum placed them in need of protections similar to those available to matrons, but also to priests and those magistrates who offered

\footnotetext{
${ }^{44}$ Cf. Roller 2004, 48 n. 111: "Because Cloelia is not an adult, the toga does not imply she is a prostitute." Sebesta 1994, 46-7; Olson 2008a, 141-2.

${ }^{45}$ Livy 8.9.4, 27.8.8, 34.7.2; Serv. Aen. 8.552; Plut. Mor. 283B; CIL II ${ }^{2}$ 5, 1022 col. 19.21-2, col. 21.7-8. Stone 1994, 13.

${ }^{46}$ Sebesta 1997, 532-3, 2005; cf. Fowler 1896. See also Edmondson 2008, 26; Scipio Aemilianus ap. Macrob. Sat. 3.14.7; Cic. Verr. 2.3.159; Val. Max. 6.praef., 8.1.absol.8; Plin. HN 9.127. Sexual assault on a freeborn child (male or female) constituted another form of stuprum: Dig. 47.11.1.2 (Paul), 48.5.6.1 (Papinian), 48.5.35.1 (Modestinus); Fantham 1991, 271; Williams 1999, 96.
} 
sacrifices on behalf of the state. "The law commands that one attend upon the gods chastely," explains Cicero (caste iubet lex adire ad deos, Leg. 2.24). ${ }^{47}$

The proposed connection between these sexual taboos and the purple border of the toga praetexta explains not only why children regularly served as ritual ministrants and acolytes, but also why the Vestal virgins, who took the principle of religious castitas to extraordinary lengths, wore a purple-bordered suffibulum when participating in sacrificial rites. ${ }^{48}$ Of course, the veil itself can be read as a sign of sexual modesty, a fact which applies equally to the Vestal suffibulum as to the bridal flammeum. ${ }^{49}$ Returning to those elements of costume that the Vestals shared with brides, we find the same principle of sexual differentiation at work in these features as well. As a mark of status available to matrons, brides, and virgins alike, vittae were used to contrast the honorable status of these female roles with that of prostitutes, whom Servius explains were not allowed to wear hairbands (ad Aen. 7.403), and other females of dubious integrity, such as slaves. ${ }^{50}$ Ovid thus describes thin vittae (together with the long instita, or lower border of the stola) as a "sign of chastity" (insigne pudoris, Ars am. 1.31), which he would

${ }^{47}$ Cicero (loc. cit.) would privilege purity of mind over purity of the body, which for religious purposes could be obtained by washing with water or a period of abstinence. Cf. Varro Antiquitates Rerum Divinarum 123S ap. Non. 289-90L; Sen. Controv. 1.2.7. ${ }^{48}$ Festus 474L, quoted above. See also [Quint.] Decl. 340.13. For children's roles in sacrificial rites, see Col. Rust. 12.4.3; ILS 5039; Festus 82L; Serv. Aen. 11.543; Ryberg 1955, 21 n. 10 and passim, Mantle 2002, 85-102.

${ }^{49}$ Levine 1995, 104.

${ }^{50}$ Depictions of vittae on the funerary images of freedwomen can be interpreted as "precious symbol(s) of newly attained respectability" (Fantham 2008, 168; cf. Hughes 2007). Note also the underlying logic of Plaut. Mil. 790-3, where Palaestrio proposes to disguise a young prostitute as a matron (ex matronarum modo) by putting her hair up in vittae. 
banish from his erotic poetry. ${ }^{51}$ This connection is reinforced by its negation in an overlooked passage from Ovid's account of the dream that foretold Rhea Silvia's impregnation by Mars, in which he describes the Vestal's hair coming loose from its bindings as a potent symbol of her defeated chastity (Fast. 3.29-30). ${ }^{52}$ Dionysius of Halicarnassus reports that the Vestal Opimia, whose condemnation for incestum is assigned to the year 483 B.C.E., was stripped of her headbands ( $\sigma \tau \dot{\varepsilon} \mu \mu \alpha \tau \alpha)$ before she was brought to her place of punishment (Ant. Rom. 8.89.5). Just as the wearing of the stola (as opposed to the toga) signaled the difference between the chaste and unchaste woman's body, the binding of one's hair with vittae accomplished a similar distinction for females of all ages.

It follows that the hairstyle of the seni crines, which I have argued was dependent on the use of vittae to keep its braids in place, can be regarded as an even more emphatic expression of the wearer's chastity. This is in keeping with what a corrupt passage of Festus, our only testimony about the nature of the seni crines, seems to suggest about the hairstyle's significance for brides $(454 \mathrm{~L})$ :

Senis crinibus nubentes ornantur, quod [h]is ornatus vetustissimus fuit. Quidam quod eo Vestales virgines ornentur, quarum castitatem viris suis $\uparrow$ sponoe $* * *$ a ceteris.

${ }^{51}$ Levine 1995, 103; McGinn 1998, 154; Hersch 2010, 88. Cf. Ov. Ars am. 2.600, Tr. 2.251-2; Tib. 1.6.67-8. On the interpretation of the instita, see Serv. Aen. 2.616; Olson 2008b, 30. ${ }^{52}$ The description of lapsa ... lanea vitta is probably a reference to vittae interwoven with the ritual infulae rather than to the woolen infulae themselves. Cf. Fantham 2008, 164 on the difficulty of fitting the latter word into hexameters. Women in mourning also unbound their hair (Plut. Mor. 267A; cf. Ov. Met. 9.771), as did Maenads (Ov. Met. 4.6). On hair as a locus of female eroticism, see Leach 1958; Levine 1995, 91-110; Sebesta 1997, 533; Llwewllyn-Jones 2003, 263-5. 
Brides are adorned with the seni crines because it was the[ir] most ancient form of adornment. Certain (writers have argued?) that they do so because the Vestal virgins are adorned with it, whose chastity (brides emulate?) for their husbands in marriage(?).

Whether or not brides consciously emulated the fashion of the Vestals, the shared usage of this coiffure by both types of women can be explained by a common interest in providing an outward representation of the wearer's castitas. ${ }^{53}$

As for the belt fastened with the nodus Heraculaneus, the proliferation of apotropaic and curative uses for knots in ancient magical and medical practice necessarily renders any discussion of this feature's significance in the context of Roman religion speculative.$^{54}$ As a practical matter, the importance of the square (or reef) knot can be explained by the fact that it only binds itself tighter when placed under stress, which makes it a fastening of great strength, much like its ancient namesake. ${ }^{55}$ Just as the vittae that bound the hair were a sign of chastity, a belt (whether that of a Vestal or the woolen cingulum of a bride) tied with such a sturdy knot would signify a sexuality that was especially well guarded. ${ }^{56}$

${ }^{53}$ La Follette 1994, 56-7; cf. Hersch 2010, 74-6.

${ }^{54}$ Plin. HN 28.42, 48, 64, 93, 218; cf. PGM IV 1084, VII 210, 370-71, 436-8, 452-3. RE 17.1, 803-9 s.v. "Nodus" (Keyssner); Day 1967, 46-74. Note also the precautions taken against the flamen Dialis coming into contact with any kind of knot: Gell. NA 10.15.8-9; cf. Paul. Fest. 72L; Serv. Aen. 4.518.

${ }^{55}$ Heraclas, ap. Oribasius Collectiones Medicae 48.8; Day 1967, 117-18.

${ }^{56}$ Hersch 2010, 109; cf. Sebesta 1997, 535. The bride's Hercules knot could only be untied by her husband on the wedding night (hunc ... vinctum vir solvit, Paul. Fest. 55L). 
To conclude, I want to review two basic points I have made about the significance of the Vestals' wardrobe. First, I have argued that overlapping boundaries were a normal feature of the Roman system of dress as a whole. One can point to a number of cases in which an exclusive relationship did exist between a social category and a particular article of clothing (e.g., the elaborately laced shoes, or calcei patricii, of the patrician order and the spike-topped cap, or apex, of the flamines $).{ }^{57}$ Overemphasis on such unique designators of status, however, creates a distorted impression of the broader process whereby sartorial habits produced social meanings in Roman culture. Whereas the powers that be were undoubtedly wary of anyone who tried to usurp the position and privileges that went with certain garments, the fact that the members of one group regularly wore articles of clothing associated with another group did not necessarily imply any confusion of categories. ${ }^{58}$ The similarities between the Vestals' costume and that of other kinds of women did not necessarily render their position in Roman society ambiguous, therefore.

Insofar as garments such as the stola or vittae were worn by Vestals, matrons, and/or brides, these items could not indicate discrete social categories in themselves. Instead, they should be understood as marking some aspect of identity that women of each status held in common. For the clothing of the Vestal virgins, I have argued that this point of correspondence was, invariably, their sexual purity. This conclusion is hardly remarkable, seeing that the Vestals' virginity is widely recognized as the single most important aspect of their religious identity. What is noteworthy, however, is that through the medium of dress such an extreme form of purity should have been made comparable to other, less restrictive, types of chastity. It is often assumed that there was an important difference between the total abstinence from sex required of

${ }^{57}$ Calceii patricii: ILS 59; Isid. Etym. 19.34.4. Apices: ILS 4; Livy 6.41.9; Paul. Fest. 17L, Serv. Aen. 8.552.

${ }^{58}$ Cf. Reinhold 1971; Edmondson 2008, 31-2. 
the Vestal virgins and the more temporary and circumstantial restrictions imposed by other forms of ritual castitas or the pudicitia of brides and matrons. ${ }^{59}$ The Vestals' clothing calls this assumption into question, as does the paean to Pudicitia that opens the sixth book of Valerius Maximus' Facta et Dicta Memorabilia (6.1.praef.):

Unde te virorum pariter ac feminarum praecipuum firmamentum, Pudicitia, invocem? tu enim prisca religione consecratos Vestae focos incolis, tu Capitolinae Iunonis pulvinaribus incubas, tu Palatii columen Augustos penates sanctissimumque Iuliae genialem torum adsidua statione celebras, tuo praesidio puerilis aetatis insignia munita sunt, tui numinis respectu sincerus iuventae flos permanet, te custode matronalis stola censetur.

From where shall I invoke you, Chastity, you mainstay of equal importance for both men and women? For you dwell at the hearth of Vesta, consecrated by ancient rites; you rest upon the couch of Capitoline Juno; you attend upon the heights of the Palatine, the Augustan penates, and Julia's most sacred marriage bed with constant vigilance. Under your guard, the signs of boyhood are kept safe; out of regard for your power, the flower of youth remains pure; with you as its protector, the matronal stola is valued.

${ }^{59}$ Beard 1980, 12-13; Cancik-Lindemaier 1990, 14-15; Staples 1998, 147-8; Parker 2004, 566; Kroppenberg 2010, 428. On the conceptual relationship between castitas and pudicitia, see Non. $707 \mathrm{~L}$. 
The concept of chastity applied here is a broad one, encompassing the cult of Vesta, the moral integrity of the imperial household, as well as the social conventions whereby children and married women were protected by their clothes.

Defined in these terms, Roman matrons had more in common with maidens (and Vestals) than they did with other non-virginal women. In contrast, the modern clinical category of "sexually active females," which we might use to distinguish matrons from Vestals, is not one that the Romans would have recognized or accepted. ${ }^{60}$ Chastity, not physical virginity, was the essential criterion of status. Overdetermined as it may have been, the castitas of the Vestal virgins was nevertheless regarded as directly comparable to that of other women. Cicero implies as much when he ascribes an exemplary function to the Vestal cult: "there are six virgins to attend upon (Vesta) so that ... women may perceive that it is the nature of women to submit wholly to chastity." (ei colendae $<V I>$ virgines praesint, ut ... sentiant mulieres \{in\} naturam feminarum omnem castitatem pati, Leg. 2.29) ${ }^{61}$ Keeping in mind the historical distance that lies between ancient and modern constructions of gender, we may wish to take this explanation seriously.

The problem, of course, is that we cannot know if Cicero is telling the truth. Did women really look to the Vestal virgins as models of proper conduct? For that matter, did they

${ }^{60}$ Sissa 1990, esp. 105-23. Cf. Parker 1997, 55-6, 58-9.

${ }^{61}$ Powell's text, modified. Wissowa's supplement of $<V I>$ before virgines is justified not just by the fact that their number permits them to attend to the fire more easily (advigiletur facilius ad custodiam ignis, omitted in the ellipsis), but also by the fact that the previous sentence refers to singuli singulorum (sc. deorum) sacerdotes. Cf. Guizzi 1968, 102. Wildfang $(2006,52)$ construes this passage to suggest that Cicero is offering multiple explanations for the Vestals' virginity. On my reading, their virginity is explained by their exemplary function, while the demanding nature of their work explains the fact that there were six of them. 
necessarily understand their own clothing through the proscriptive matrix of sexual restrictions that I have outline above? ${ }^{62}$ One of the crucial insights of recent scholarship on Roman dress is a recognition of the extent to which the sartorial ideals promulgated by the authors of our literary texts did not necessarily correspond with actual social practice, which was neither as static nor as monolithic as these sources tend to suggest. ${ }^{63}$ It was possible for women to rebel against the norms, and in so doing, to change them. The moral panic that swept through Tiberius' senate at the prospect of matrons abandoning their stolae (as recorded by Tert. de Pallio 4.9) has already been mentioned. It is also interesting to note that few representations of vittae have been identified among the increasingly elaborate coiffures that adorn the portrait heads of respectable Roman women in the early Principate. ${ }^{64}$

Such innovations, however, do not seem to have affected the Vestal virgins, who are invariably depicted with their hair carefully bound up in the seni crines to indicate their special status. As women of wealthy families became more and more accustomed to the use of jewelry, colorful silks, and cosmetics - a social reality against which Cato the Censor railed in vain already at the start of the second century B.C.E. - the Vestal's modest custom of wearing all white, save for the purple border of the suffibulum, would not have seemed bridal or matronal so

\footnotetext{
${ }^{62}$ Cf. Butler 1990, 36-43.

${ }^{63}$ Stone 1994; Olson 2002, 389-92, 2008b: 2-4, 11; Edmondson 2008, 38-9. See also Barthes 1983, 3-10.

${ }^{64}$ Olson 2002, 392; Fantham 2008, 166-8. Wood $(1999,98)$ suggests that the vittae were originally depicted using paint, but this explanation seems unsatisfactory, given the intricacy with which the carving of hairstyles is typically executed.
} 
much as rigorously traditional—religiosus in the fundamental sense of the term. ${ }^{65}$ Livy records a case from the early history of the Republic in which a Vestal named Postumia was accused of incestum "because of adornment more pleasing and a spirit more free than is fitting for a virgo" (propter cultum amoeniorem ingeniumque liberius quam virginem decet, 4.44.11). She was acquitted of the principal charge, but still received a stern warning from the pontifex maximus, who ordered her to refrain from witticisms and to dress "sacredly rather than skillfully" (colique sancte potius quam scite iussit, 4.44.12). ${ }^{66}$ Confined not just by the social conventions that governed their sex but by strict religious regulations as well, the Vestal virgins held out more strongly than most women against the changing trends of fashion, thereby providing an essential anchor for Roman attitudes regarding the connection between a woman's chastity and her manner of dress. At the very least, this vestimentary conservatism presented men with an ideal against which to measure the conduct of their own wives and daughters.

The extent to which the Vestals internalized the logic of this dress code themselves is difficult to assess, but probably should not be underestimated. The risk of being charged with incestum and possibly buried alive represented a powerful motive for conformity, of course, but so did the special honors and privileges that these priestesses enjoyed as a reward for their sacred

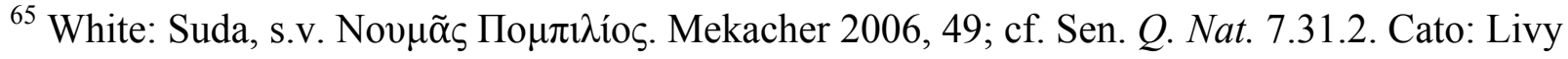
34.1-4; Olson 2002, 398-400, 2008b 100-4, cf. 80-95. Note that Festus (454L) describes the seni crines as not just chaste, but vetustissimus.

${ }^{66}$ Cf. Plut. Mor. 89F. On the authority of the pontifices over trials for incestum, see Lovisi 1998, 715-19. Note also Ov. Fast. 4.309-10 on Claudia Quinta, whose dress and bearing raised suspicions about her status as a casta matrona - in other accounts, she was a Vestal virgin (Sen. ap. Jer. adv. Iovinian. 41; Gallia 2012, 122).
} 
chastity. ${ }^{67}$ The same senators who sought to penalize matrons for going out without their stolae in the reign of Tiberius also bestowed a gift of two million sestertii on the newly inducted Vestal virgin Cornelia in 23 C.E. According to Tacitus, this was done "so that the priestesses' stature might increase and their spirits might become more eager to perform their rites" (utque glisceret dignatio sacerdotum atque ipsis promptior animus foret ad capessendas caerimonias, Ann.

4.16.4). The recipients of such largess might well be expected to accept the ideological formulations upon which it was predicated.

Sixty-eight years later, a different Vestal named Cornelia would be condemned for incestum under Domitian's authority as pontifex maximus - perhaps unjustly, as the younger Pliny implies (Ep. 4.11.6) ${ }^{68}$ That this Cornelia continued to insist upon her innocence is not surprising, but the way in which she came closest to proving it is worth noting as well (Plin. Ep. 4.11.9):

Quin etiam cum in illud subterraneum demitteretur, haesissetque descendenti stola, vertit se ac recollegit, cumque ei manum carnifex daret, aversata est et resiluit foedumque contactum quasi plane a casto puroque corpore novissima sanctitate reiecit

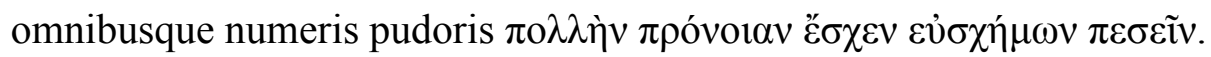

\footnotetext{
${ }^{67}$ The latter point is made with invective pointedness by Ambrose, Ep. 18.11. Vestal privileges included, inter alia, special seats at the games (Cic. Mur. 73), the service of a public herald, or lictor (Sen. Controv. 1.2.3), and the right to conduct business without the interference of a male guardian (Plut. Num. 10.3; Gai. Inst. 1.145). See Mekacher 2006, 28-31; also Guizzi 1968, 3-31, 159-200.

${ }^{68}$ Gallia 2012, 91-127; cf. Mekacher 2006, 107.
} 
While she was being sent down into that underground chamber, her stola impeded her as she was climbing down and she turned to gather it up. When the executioner offered his hand, she turned away and with a final display of holiness repelled that shameful contact as though from an obviously pure and chaste body. And so, with every enumeration of her modesty, "she took great precautions to fall properly." 69

After almost three decades of service as a Vestal, this Cornelia seems to have developed a deep appreciation for the way her garments safeguarded the purity of her body. By avoiding the outstretched hand of the carnifex, she was able to demonstrate her devotion to chastity even as the emperor sought to punish an alleged transgression. Innocent or not, her actions reaffirmed in stark terms the importance of clothing to the sacred identity of the Vestal virgins. ${ }^{70}$

University of Minnesota

\footnotetext{
${ }^{69}$ Pliny's Greek quotation comes from Euripides' account of the death of another virgin, Polyxena (Hec. 569).

${ }^{70}$ I would like to thank Elizabeth Asmis and the anonymous referees for $C P$, whose suggestions prompted many improvements of this text. Remaining deficiencies are mine alone.
} 


\section{LITERATURE CITED}

Barthes, Roland. 1983. The Fashion System, trans. Matthew Ward and Richard Howard. New York.

Beard, Mary. 1980. The Sexual Status of Vestal Virgins. JRS 70: 12-27.

- 1995. Re-reading (Vestal) virginity. In Women in Antiquity: New Assessments, ed. Richard Hawley and Barbara Levick, 166-77. London.

Butler, Judith. 1990. Gender Trouble: Feminism and the Subversion of Identity. New York and London.

Cancik-Lindemaier, Hildegard. 1990. Kultische Privilegierung und gesellschaftliche Realität: Ein Beitrag zur Sozialgeschichte der virgines Vestae. Saeculum 41: 1-16.

Davies, Glenys. 2005. What Made the Roman Toga virilis? In The Clothed Body in the Ancient World, ed. Liza Cleland, Mary Harlow and Lloyd Llewellyn-Jones, 121-30. Oxford.

Day, Cyrus L. 1967. Quipus and Witches' Knots: The Role of the Knot in Primitive and Ancient Cultures. Lawrence, KS.

Douglas, Mary. 1969. Purity and Danger: An analysis of the concepts of pollution and taboo ${ }^{2}$. London.

Dragendorff, Hans. 1896. Die Amtstracht der Vestalinnen. RhM 51: 281-302.

Dyck, Andrew. R. 2001. Dressing to Kill: Attire as a Proof and Means of Characterization in Cicero's Speeches. Arethusa 34: 119-30.

Edmondson, Jonathan. 2008. Public Dress and Social Control in Late Republican and Early Imperial Rome. In Edmondson and Keith 2008, 21-46.

Edmondson, Jonathan and Alison Keith, eds. 2008. Roman Dress and the Fabrics of Roman Culture. Toronto. 
Edwards, Catharine. 1993. The Politics of Immorality in Ancient Rome. Cambridge.

El Guindi, Fadwa. 1999. Veil: Modesty, Privacy and Resistance. Oxford and New York.

Fantham, Elaine. 1991. Stuprum: Public Attitudes and Penalties for Sexual Offences in Republican Rome. EMC n.s. 10: 267-91.

— 2008. Covering the Head at Rome: Ritual and Gender. In Edmondson and Keith 2008, $158-71$.

Fausto-Sterling, Anne. 2000. Sexing the Body: Gender Politics and the Construction of Sexuality. New York.

Fowler, W. Warde. 1896. On the Toga Praetexta of Roman Children. CR 10: 317-19.

Gallia, Andrew B. 2012. Remembering the Roman Republic: Culture, Politics, and History under the Principate. Cambridge and New York.

- 2015. Vestal Virgins and their Families. CA 34: 74-102.

Gardner, Jane F. 1986. Women in Roman Law and Society. Bloomington.

Giannecchini, Giulio. 1980-81. Seni Crines. AFLPer (Clas) 18: 91-92.

Guizzi, Francesco. 1968. Aspetti giuridici del sacerdozio romano: Il sacerdozio di Vesta. Naples.

Hersch, Karen K. 2010. The Roman Wedding: Ritual and Meaning in Antiquity. Cambridge.

Heskel, Julia. 1994. Cicero as Evidence for Attitudes to Dress in the Late Republic. In Sebesta and Bonfante 1994, 133-45.

Hughes, Lisa A. 2007. Unveiling the Veil: Cultic, status, and ethnic representations of Early Imperial freedwomen. Material Religion 3: 218-241.

Jordan, Henri. 1886. Der Tempel der Vesta und das Haus der Vestalinnen. Berlin.

Kroppenberg, Inge. 2010. Law, Religion, and Constitution of the Vestal Virgins. Law \& Literature 22: 418-39. 
La Follette, Laetitia. 1994. The Costume of the Roman Bride. In Sebesta and Bonfante 1994, 5464.

La Follette, Laetitia and Rex Wallace 1993. Latin seni crines and the Hair Style of Roman Brides. SyllClass 4: 43-48.

Leach, Edmund. 1958. Magical Hair. JRAI 88: 147-64.

. 1976. Culture and communication: the logic by which symbols are connected. Cambridge.

Lévi-Strauss, Claude. 1955. The Structural Study of Myth. Journal of American Folklore 68: 428-44 (= id., Structural Anthropology, 206-32).

Levine, Molly Myerowitz 1995. The Gendered Grammar of Ancient Mediterranean Hair. In Off with Her Head! The Denial of Women's Identity in Myth, Religion, and Culture, ed. Howard Eilberg-Schwartz and Wendy Doniger, 76-130. Berkeley.

Llewellyn-Jones, Lloyd. 2003. Aphrodite's Tortoise: The Veiled Woman of Ancient Greece. Swansea.

Lovisi, Claire. 1998. Vestale, incestus et juridiction pontificale sous la république romaine. MÉFRA 110: 699-735.

Mantle, Inga C. 2002. The Roles of Children in Roman Religion. G\&R 49: 85-106.

Martini, Maria Cristina. 1997. Carattere e struttura del sacerdozio delle Vestali: un approccio storico-religioso. Latomus 56: 245-63, 477-503.

-2004. Le vestali. Un sacerdozio funzionale al “cosmo” romano. Brussels.

McGinn, Thomas A. J. 1998. Prostitution, Sexuality, and the Law in Ancient Rome. Oxford. Mekacher, Nina. 2006. Die vestalischen Jungfrauen in der römischen Kaiserzeit. Wiesbaden. 
Olson, Kelly. 2002. Matrona and Whore: The Clothing of Women in Roman Antiquity. Fashion Theory 6: 387-420.

—. 2008a. The Appearance of the Young Roman Girl. In Edmondson and Keith 2008, 13957.

-2008b. Dress and the Roman Woman: Self-presentation and society. London and New York.

Parker, Holt N. 1997. The Teratogenic Grid. In Roman Sexualities, ed. Judith P. Hallett and Marilyn B. Skinner, 47-65. Princeton.

- 2004. Why Were the Vestals Virgins? Or the Chastity of Women and the Safety of the Roman State. AJP 125: 563-601.

Powell, J. G. F. 2006. M. Tulli Ciceronis. De re publica, De legibus, Cato Maior de senectute, Laelius de amicitia. Oxford.

Reinhold, Meyer. 1971. Usurpation of Status and Status Symbols in the Roman Empire. Historia 20: $275-302$.

Roach, Mary Ellen and Joanne Bubolz Eicher. 1965. Dress, Adornment and the Social Order. New York.

Roller, Matthew B. 2004. Exemplarity in Roman Culture: The Cases of Horatius Cocles and Cloelia. CP 99: 1-56.

Ryberg, Inez Scott. 1955. Rites of the State Religion in Roman Art. MAAR 22. Rome.

Scardigli, Barbara. 2003. Vestali integrante nella società romana. SHHA 21: 97-104.

Sebesta, Judith Lynn. 1994. Symbolism in the Costume of the Roman Woman. In Sebesta and Bonfante 1994, 46-53. 
1997. Women's Costume and Feminine Civic Morality in Augustan Rome. Gender \& History 9: 529-41.

- 2005. The toga praetexta of Roman Children and Praetextate Garments. In The Clothed Body in the Ancient World, ed. Liza Cleland, Mary Harlow and Lloyd Llewellyn-Jones, 114-20. Oxford.

Sebesta, Judith Lynn and Larissa Bonfante, eds. 1994. The World of Roman Costume. Madison.

Sensi, Luigi. 1980-81. Ornatus e status sociale delle donne romane. AFLPer (Class) 18: 55-102.

Siebert, Anne Viola. 1995. Quellenanalytische Bemerkungen zu Haartracht und Kopfschmuck römischer Priesterinnen. Boreas 18: 77-92.

Sissa, Giulia. 1990. Greek Virginity, trans. Arthur Goldhammer. Cambridge, MA.

Staples, Ariadne. 1998. From Good Goddess to Vestal Virgins: Sex and category in Roman religion. London and New York.

Stephens, Janet. 2013. Vestal Hairdressing: recreating the 'Seni Crines'. [Video file]. Retrieved from http://www.youtube.com/watch?v=eA9JYWh1r7U.

Stone, Shelly. 1994. The Toga: From National to Ceremonial Costume. In Sebesta and Bonfante 1994, 13-45.

Torelli, Mario. 1984. Lavinio e Roma: Riti iniziatici e matrimonio tra archeologia e storia. Rome.

Treggiari, Susan. 1991. Roman Marriage. Iusti Coniuges from the Time of Cicero to the Time of Ulpian. Oxford.

van Deman, Esther Boise. 1908. The Value of the Vestal Statues as Originals. AJA 12: 324-42.

Wildfang, Robin Lorsch. 2006. Rome's Vestal Virgins: A study of Rome's Vestal priestesses in the late Republic and early Empire. London and New York. 
Williams, Craig A. 1999. Roman Homosexuality: Ideologies of Masculinity in Classical Antiquity. Oxford.

Wood, Susan E. 1999. Imperial Women: A Study in Public Images, 40 B.C. - A.D. 68. Leiden. 